\title{
Association of ACE, AGT and AT1R gene polymorphisms with severity of Coronary Artery Disease
}

\author{
Dr. Nirupama Devi ${ }^{1}$, Dr. V. Lakshmi ${ }^{2}$, Dr. Karunakara Padhy ${ }^{3}$, \\ Prof. P. Veerraju ${ }^{4}$ Prof. Srikrushna Mahapatra ${ }^{5}$ \\ ${ }^{1}$ Assistant professor, Department of Biochemistry, M.K.C.G Medical college, Berhampur, Odisha,India \\ ${ }^{2}$ Assistant professor, Department of Human Genetics, Andhra University, Visakhapatnam \\ ${ }^{3}$ Consultant and HOD, Cardiothoracic Surgeon, Care Hospital, Visakhapatnam,A.P \\ ${ }^{4}$ UGC Emeritus Fellow, Department of Anthropology, Andhra University, Visakhapatnam A.P \\ ${ }^{5}$ Professor and HOD, Department of Biochemistry, M.K.C.G Medical college, Berhampur
}

\begin{abstract}
Coronary Artery Disease (CAD) is one of the most frequent causes of morbidity and mortality. A both environmental and genetic factor contributes to the development of CAD. Renin angiotensin system which regulates blood pressure plays an important role in pathogenesis of CAD. Angiotensinogen (AGT), Angiotensin converting enzyme (ACE) and angiotensin II type 1 receptor (ATIR) are the major components of Renin Angiotensin System (RAS).

Objective of the study is to examine whether these RAS component gene polymorphisms have any impact on severity of $C A D$.

A total of 150 CAD cases mostly acute myocardial infarction (78\%) and unstable angina (22\%) were included in the study. Nearly age and sex matched 150 healthy controls were taken for comparison. The severity of disease was classified as Single Vessel Disease (SVD), Double Vessel Disease (DVD) and Triple Vessel Disease (TVD).Gene polymorphisms were studied by PCR-RFLP method.

The mean age of the patients was $54.6 \pm 11.4$ years. Most common risk factor for CAD was hypertension (48.6\%). Among the total 150 CAD cases, 54.6\% had Triple Vessel Disease. TVD was most frequently associated with DD of ACE $(P<0.001)$ and TT of AGT genotype $(P=0.016)$ when compared to DVD and SVD. Risk genotypes of ACE and AGT might influence the severity of disease. So genotype may predict prognosis and outcome of coronary artery disease.
\end{abstract}

Key words: Coronary Artery Disease, severity, Renin Angiotensin System, Gene polymorphism

\section{Introduction}

The term Coronary Artery Disease (CAD) or Ischaemic Heart Disease (IHD) defines a disease spectrum of diverse aetiology with common factor being an imbalance between myocardial oxygen supply and demand ${ }^{1}$.

Coronary artery disease is the most common cause of death. The WHO estimated that in 2002, $12.6 \%$ of deaths worldwide were from CAD ${ }^{2}$. Coronary artery disease is the leading cause of death in the developed countries, but third to AIDS and lower respiratory tract infection in developing countries ${ }^{3}$.

In India also Coronary Artery Disease (CAD) is the leading cause of death ${ }^{4}$. Although a relatively new epidemic in India, it has quickly become a major health issue with death due to CAD expected to double by $2015^{5,6}$. According to WHO report 2002, CVD are projected to be the largest cause of death and disability by 2020, with 2.6 million Indians predicted to die due to Coronary artery disease predominantly with Myocardial Infarction (MI). Mortality estimates due to CAD vary widely with State, ranging from $10 \%$ in Meghalaya to 49\% in Punjab. Punjab (49\%), Goa (42\%), Tamil Nadu (36\%) and Andhra Pradesh (31\%) have the highest CAD related mortality estimates ${ }^{7}$.CAD affects Indians at a younger age (in their $30 \mathrm{~s}$ and $40 \mathrm{~s}$ ) compared to western countries.

CAD in Asian Indians is known to be severe, extensive and malignant ${ }^{8,9}$. This gives information regarding the accelerated atherosclerotic process that begins early in life.

Enas and Senthilkumar, reported high rate of CAD in Asian Indians in USA which is accompanied by low rate of conventional risk factors ${ }^{10}$. The same was also revealed by CADI (coronary artery disease in Indians) study. So the high prevalence of CAD among Asian Indians despite low incidence of risk factors suggests an important role of genetic risk factors.

There are established conventional risk factors like age, male sex, family history, hypertension, diabetes mellitus, smoking, dyslipidemia and obesity for CAD. Together with environmental factors, the involvement of multiple genes is also responsible for coronary artery disease ${ }^{11}$.

Subjects having systolic blood pressure $\geq 140 \mathrm{mmHg}$ and / or diastolic $\geq 90 \mathrm{mmHg}$ or current use of antihypertensive medication are considered as hypertensives. Fasting blood glucose level of $126 \mathrm{mg} / \mathrm{dl}$ or greater 
are considered as diabetes. Serum total cholesterol level more than $200 \mathrm{mg} / \mathrm{dl}$ are hyperlipidemic. Obesity is defined as a body mass index (BMI) (weight in kg divided by the square of height in meters) of $\geq 30 \mathrm{~kg} / \mathrm{m}^{2}$ and overweight as $25-29.9 \mathrm{~kg} / \mathrm{m}^{2}$.

\section{Cad And Genes}

There are various candidate genes have been studied for the pathophysiology and clinical symptoms for coronary atherosclerosis 12,13 .

The renin-angiotensin system (RAS) or the renin - angiotensin -aldosterone system (RAAS) has an important role in the pathogenesis of atherosclerosis. This enzyme cascade is a hormone system that regulates blood pressure, fluid and electrolyte balance ${ }^{14}$

The main polymorphic gene component of RAS are angiotensinogen (AGT), angiotensin converting enzyme (ACE) and angiotensin II type 1 receptor(AT1R) gene ${ }^{15}$.

The severity depends on the number of vessels involved and the degree of stenosis evaluated by coronary angiogram. Patients were classified according to the number of significant stenotic vessels (vessels with more than 50\% narrowing ) as Single Vessel Disease (SVD), Double Vessel Disease (DVD) and Triple Vessel Disease (TVD).The progression and extent of disease is extremely variable and do not depend on the conventional risk factors.

\section{Objectives Of Study}

The aim of the present study is to see the association of RAS gene polymorphisms with the severity of CAD in patients of north coastal Andhra Pradesh.India.

\section{Study Population}

\section{Materials And Methods}

A total of 150 CAD patients (unstable angina and acute myocardial infarction) and 150 healthy controls were included in the present study. Patients attending in-patient and out-patient departments of cardiology and cardiothoracic surgery unit of Care Hospital, The institute of medical sciences, Visakhapatnam, Andhra Pradesh (India) were included in the study after obtaining their informed consent. The study is approved by the Institutional Ethics Committee for research on human volunteers of Andhra University, Visakhapatnam. Patients were mainly from north coastal Andhra Pradesh which constitutes three districts (Visakhapatnam, Vizianagaram and Srikakulam). Normal healthy controls were also collected from the same region with informed consent. The period of study was from 2007-2011.

\section{Sample Collection}

With prior informed consent, $6 \mathrm{ml}$ of peripheral blood was collected from 150 CAD cases and controls. Four ml of blood was collected into sterile centrifuge tubes containing $100 \mu \mathrm{l}$ of $15 \%$ EDTA solution. Two ml of blood was allowed to clot for serum separation. Collected EDTA whole blood samples were transported to Department of Human Genetics, Andhra University, and Visakhapatnam for further analysis. Serum parameters like blood sugar and lipid profile were tested in Care Hospital Laboratory, maintaining internal (BIORAD QC sera) and external quality control (with CMC Vellore). Coronary angiogram was done in all cases to know the number of blocks in vessel and the severity of disease.

\section{Dna Isolation}

Total DNA was extracted using non-enzymatic method described by Lahiri and Nurnberger, (1991) ${ }^{16}$.

\section{Genotyping Of The Ace Gene I/D ( Rs 4340 ) Polymorphism}

ACE gene was amplified by polymerase chain reaction (PCR) according to the method suggested by (Stone king et al, 1997) with primers from sigma laboratories ${ }^{17}$.

Forward primer :5'-CTGGAGACCACTCCCATCCTTTCT-3'

Reverse primer :5'-GATGTGGCCATCACATTCGTCAGAT-3'

The amplified PCR product was separated on $2 \%$ agarose gel. The PCR products were of $490 \mathrm{bp}$ for allele I and $190 \mathrm{bp}$ for allele D.

\section{Genotyping Of The Agt M235t ( rs 699 ) Gene Polymorphism}

AGT M235T genotype was determined by PCR amplification followed by digestion with restriction enzyme Tthl III (fermentas) according to the described method (Russ et al, 1993) ${ }^{18}$. Primers are procured from sigma laboratories as follows

Forward primer : 5'-CCGTTTGTGCAGGGCCTGGCTCTCT- 3'

Reverse primer : 5'-CAGGGTGCTGTCCACACTGGACCCC- 3' 
Digested products were run by $2 \%$ agarose gel electrophoresis. The products were of $165 \mathrm{bp}$ for allele $\mathrm{M}$ and $141 \mathrm{bp}$ for allele $\mathrm{T}$.

\section{Genotyping Of The At1r A1166c ( rs 5186 ) Gene Polymorphism}

For the analysis of the A/C polymorphism of the AT1R gene PCR protocol (Hingorani et al, 1995) ${ }^{19}$ was used taking primer sequence from sigma laboratories were as follows

Forward primer : 5'-ATAATGTAAGCTCATCCACCAAGAAG-3'

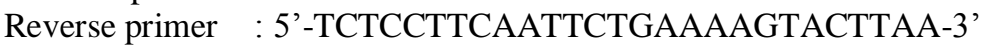

PCR product was further digested by restriction enzyme (BspTI-Afl II) from fermentas. Digested products were run by $2 \%$ agarose gel electrophoresis. The AT1R allele were visualised as fragments of $166 \mathrm{bp}$ (A) and $139 \mathrm{bp}$ (C).

\section{Statistical Analysis}

Results are expressed as percentage and mean \pm SD. Hardy- Weinberg law of equilibrium was tested for the ACE, AGT and AT1R gene polymorphism in CAD patients. Genotype distribution between cases and controls were compared by using chi-square and odds ratio (OR) with $95 \%$ confidence interval (CI). It was done by using SPSS package 16.0 version. Comparison of genotype was made between triple vessel disease with double and single vessel disease separately using two by two epidemiological calculator. For all cases $\mathrm{P}<0.05$ was considered as significant.

\section{Result}

We genotyped 150 angiographically diagnosed CAD patients. Age and sex distribution of analyzed groups are shown in (Table 1). Maximum numbers of patients were of 51-60 years with a M: F Ratio of 121:29. The mean age of the patients was $54.6+/$ - 11.4. Risk factor profile of CAD patients (Table II) revealed hypertension in $48.6 \%$, diabetes mellitus in $33.3 \%$, dyslipidemia in $27.3 \%$, and smoking in $26.0 \%$ and obesity in $6.0 \%$.

Out of 150 cases, $54.6 \%$ were TVD, $34.0 \%$ were SVD and $11.3 \%$ of cases were DVD. According to clinical presentation 117 were of acute myocardial infarction cases and 33 cases were unstable angina. Inhospital death was there in 5.3\% of cases (Table III).

Genotype distributions of total CAD cases irrespective of vessel disease were compared with normal healthy controls in Table IV. Frequency of ACE DD was 4.5 times higher $(\mathrm{p}=0.03)$ and AGT TT was 12.61 times higher $(\mathrm{p}=0.0003)$ in cases when compared to controls.

About $22.6 \%$ of the patients had no risk factors. Cases with or without risk factors were compared among themselves according to the severity of disease (Table V). The percentage of Triple vessel disease was found almost similar in both the groups.

\section{Genotype distribution and allele frequencies:}

Genotypes at all genes were in the Hardy-Weinberg equilibrium. The genotypes and allele frequencies of the Alu ACE locus in patients and different groups of vessel diseases are given in Table VI. Chi-square $\left(\chi^{2}\right)$ and $p$ value were computed in subsets of the data that vary by the severity of the disease (SVD, DVD \& TVD). Genotype and allele frequencies comparison was made between TVD vs DVD and TVD vs SVD. DD genotype and D-allele were significantly more frequent in the subgroup of TVD in comparison to DVD and SVD. This result suggests the presence of an association between ACE I/D gene polymorphism and the severity of coronary artery disease.

Comparison of AGT M235T genotypes were made between TVD with DVD and SVD separately (Table VII). Chi- square $(\chi 2)$ test showed that TT genotype and T allele had a higher frequency in TVD in comparison to DVD and SVD which was statistically significant.

A genotype and allele frequency of AT1R A1166C polymorphism based on number of affected coronary vessels has been shown in table VIII. There is no CC genotype found in CAD patients which is a risk genotype. CAD patients having SVD have mostly AA genotype (96.1\%) which is a less severe genotype. But Callele had borderline significance for TVD in comparison to SVD.

\section{Discussion:}

The present study indicated a significant association of CAD with the Alu ACE I/D polymorphism, located in the intron 16 region. This association is highly significant among patient with TVD rather than with DVD or SVD. Individual with D-allele of Alu ACE locus are more susceptible to this clinical disorder. Individuals with DD genotype are more susceptible followed by ID and II genotype. In India very few authors reported association of DD genotype and D-allele with CAD ${ }^{20,21,22}$. Globally association of DD genotype with 
CAD has been also reported ${ }^{23,24,25,26,27}$. A large body of literature suggests D-allele association with myocardial infarction $28,29,30,31,32$.

Asians Indians are more susceptible to CAD has been reported ${ }^{10}$. This raises the question of genetic susceptibility due to the ACE locus. Carriers of DD genotype have elevated serum as well as cardiac ACE activity and that exposed to higher angiotension II level than II and ID genotype ${ }^{33,34}$. Angiotensin II is involved in the modulation of vascular tone and proliferation of smooth muscle cells ${ }^{22}$, stimulates $\mathrm{ca}^{2+}$, aldosterone pathway ${ }^{35}$ and vascular endothelial growth factors ${ }^{36}$ and deposition of more cholesterol in the coronary arteries to cause atherosclerotic plaque and hypertension.

Our study shows DD genotype and D-allele is strongly associated with subgroup of CAD patients having TVD. This study is in accordance with study done at Chennai, India by Emmanuel et al ${ }^{21}$. Mendonca et al and Hibi et al also reported association of DD genotype with extent and severity of coronary artery disease $\mathrm{e}^{37}$,

Looking beyond the classical risk factors for CAD many investigators have recently pursued the study of genetic factors in the renin angiotensin system to predict the development and severity of CAD. Genetic polymorphism in the angiotensinogen gene M235T increases the plasma concentration of angiotensinogen ${ }^{39}$. High allele frequencies of AGT TT genotype were observed in Asians ${ }^{40}$ and blacks ${ }^{41}$.

Angiotensinogen concentration is a limiting factor for angiotensin II generation ${ }^{42}$. Thus its increased amounts may increase Angiotensin II levels many fold, potentially promoting atheroselerosis ${ }^{43}$ or modulating the severity of $\mathrm{CAD}^{44}$. Our result shows that the genotype TT and T-allele may influence the severity of CAD as it is strongly associated with TVD through the generation of numerous and critical atherosclerotic lesion. Jeunemaitre et al $^{45}$ reported an association of the T-allele with the extent of coronary lesions. Pereira et al ${ }^{46}$ and Meheri et al ${ }^{47}$ showed that the presence of the TT genotype and T-allele was associated with the severity of CAD independent of other cardiovascular risk factors. No significant association was found by Gardeman et al ${ }^{48}$ between AGT T homozygosity and the severity of the disease in caucasians.

The AT1R receptor is a major component of the renin-angiotensin system. The AT1R receptor mediates most of the classical and biological functions of angiotensin II ${ }^{49}$. It was hypothesized that the adverse effect of the $1166 \mathrm{C}$ allele is due to the increased responsiveness to angiotensin $\mathrm{II}^{50}$.

In our study there is very less number of CAD having $1166 \mathrm{C}$ allele. No study from India was done regarding AT1R gene polymorphism and severity of CAD. Pullareddy et $\mathrm{al}^{51}$ from India reported that CC genotype is not a risk factor for MI in South Indian population. Globally many studies reported that CC genotype is not associated with $\mathrm{MI}^{52,53,54}$. Some studies reported association of $\mathrm{CC}$ homozygote genotype with MI and CHD $30,55,56,57$

In our study population among the RAS gene risk genotype of ACE and AGT polymorphism are associated strongly with severity of coronary artery disease whereas AT1R gene found to be almost normal.

\section{Conclusion}

Thus Alu ACE genotyping seems to be useful for predicting the risk of severity among CAD patients. AGT M235T polymorphism is also associated with CAD risk and influence the severity of CAD. AT1R gene polymorphism did not show any association significantly with severity. However due to our limited sample size our findings require confirmation in larger cohorts. Clinical translation of this study may help in management and predicting prognosis of CAD patients.

\section{References}

[1] Braunwald E: Ischaemic Heart Disease. Harrison's principles of internal medicine, $13^{\text {th }}$ edition, $1994 ; 1: 1077$.

[2] World Health Report 2004- Changing History. World health organisation. 2004; 120-124.

[3] Center for global, International and Regional Studies (CGIRS) at the University of California Santa Cruz. Cause of death - UC Atlas of Global Inequality. December 7, 2006.

[4] Mukherjee AK. "Prediction of coronary heart disease using risk factor categories". J Indian Med Assoc. 1995 ; 93 (8): $312-5$.

[5] Rastogi T, Vaz M, Spiegelman D, Reddy KS, Bharathi AV, Stampfer MJ, Willett WC and Ascherio1 A (2004). "Physical activity and risk of coronary heart disease in India". Int. J. Epidemiol. 2004; 33 (4): 1-9.

[6] Gupta R. . "Escalating Coronary Heart Disease and Risk Factors in South Asians". Indian Heart Journal. 2007 ; $214-17$.

[7] Gupta R, Misra A, Pais P, Rastogi P and Gupta VP. "Correlation of regional cardiovascular disease mortality in India with lifestyle and nutritional factors". International Journal of Cardiology.2006; 108 (3): 291-300.

[8] Pahlajani DB, Chawla MH, Kapashi KA. Coronary artery disease pattern in the young. J Assoc Physicians India 1989; 37:312314.

[9] Sharma SN, KaUl U, WASiR HS, MANChanda SC, BAHL VK, TAlwar KK, RAJANi M, Bhatia ML. CoRonary ARTERIOGRAPHIC PROFILE IN YOUNG AND OLD INDIAN PATIENTS WITH ISCHAEMIC HEART DISEASE: A COMPARATIVE STUDY. INDIAN HEART J. 1990; 42:365-369.

[10] Enas EA and Senthilkumar A. Coronary artery disease in Asian Indians: an update and review. The Internet Journal of Cardiolog y 2001; vol1: no 2 .

[11] Wilson PWF, D'Agostino RB, Levy D, Belanger AM, Silbershatz H, Kannel WB. Prediction of coronary heart disease using risk factor categories. Circulation 1998; 97:1837-47. 
[12] Alam MA, Husain SA, Narang R, Chauhan SS, Kabra M and Vasisht S. Association of polymorphism in the thermolabile 5,10methylene tetrahydrofolate reductase gene and hyperhomocysteinemia with coronary artery disease. Mol cell biochem. 2008; 310:111-117.

[13] Fallah, S., Seifi, M., Ghasemi, A., Firoozrai, M., Samadikuchaksaraei, A. Matrix Metalloproteinase-9 and Paraoxonase 1 Q/R192 Gene Polymorphisms and the Risk of Coronary Artery Stenosis in Iranian Subjects, J. Clin. Lab. Anal.2010; 24: 305-310,

[14] Van Geel PP, Pinto YM, Buikema H, Van Gilst WH. Is the A1166C polymorphism of the angiotensin II type 1 receptor involved in cardiovascular disease? Eur Heart J. 1998; 19:G13-17.

[15] Gomez RA Molecular biology of components of the renin-angiotensin system during development .Pediatr Nephrol 1990; 4:4213 .

[16] Lahiri DK, Bye S, Nurnberger JI Jr, Hodes ME, Crisp M. A non-organic and non-enzymatic extraction method gives high yields of genomic DNA from whole-blood samples than do nine other methods tested. J Biochem Biophys Methods 1992; 25:193-205.

[17] Stoneking M, Fonitus JJ, Cliffort SL et al. Alu insertion polymorphism and human evolution: evidence for a larger population size in Africa. Genome Res. 1997; 7: 1061-1071.

[18] Russ AP, Maerz W, Ruzicka V, Stein U, Gross W. Rapid detection of the hypertension-associated Met ${ }^{235} \rightarrow$ Thr allele of the human angiotensinogen gene. Hum Mol Genet. 1993; 2:609-610.

[19] Hingorani AD, Brown MJ. Asimple molecular assay for the C1166 variants of the angiotensin II type 1 receptor gene. Biochem Biophysics Res Commun. 1995; 213:725-9.

[20] Nair KG, Shalia KK, Ashavaid TF, et al. Coronary heart disease, hypertension, and angiotensinogen gene variants in Indian population. J Clin Lab Anal 2003; 17: 141-6.

[21] Emmanuel C, S. Kanthimathi, R. Saibabu, K. M. Cherian and A. Ramesh. Angiotensin-converting enzyme insertion/deletion genotype is associated with premature coronary artery disease in Indian population. Current Science. March 2005; vol.88, no.6: 967-972.

[22] Jamil Kaiser, Rabbani Syed and Hygriv Rao Implications of I/ D. (rs4340) polymorphism in CAD among South Indian population. International J. Medicine and Medical Sciences. 2009; Vol-1 (5): 151-157.

[23] Nakai K, Itoh C, Miura Y, Hotta K, Musha T, Itho T, Miyakawa T, Iwasaki R, Hiramori K. Deletion polymorphism of the angiotensin I-converting enzyme gene is associated with serum ACE concentration and increased risk for CAD in the Japanese. Circulation. 1994;90:2199-2202

[24] Mattu RK, Needham EW, Galton DJ, Frangos E, Clark AJ, Caulfield M. A DNA variant at the angiotensin-converting enzyme gene locus associates with coronary artery disease in the Caerphilly Heart Study. Circulation. 1995;91:270-274.

[25] Arbustini, E., Grasso, M., Fasani, R., Klersy, C., Diegoli, M., Porcu, E., Banchieri, N., Fortina, P., Danesino, C., Specchia, G. Angiotensin converting enzyme gene deletion allele is independently and strongly associated with coronary atherosclerosis and myocardial infarction. Brit. Heart J. 1995;74: 584-591.

[26] Esmeray Acartürk, Gülen Attila, Abdi Bozkurt, Onur Akplnar, Selçuk Matyar. Insertion/Deletion Polymorphism of the Angiotensin Converting enzyme gene in coronary artery diseasein southern Turkey. Journal of Biochemistry and molecular Biology. 2005;vol.38,No.4:486-490.

[27] Settin Ahmad, Rizk ElBaz, Amr Abbas, Ayman Abd-Al-Samad, Ahmed Noaman. Angiotensin-converting enzyme gene insertion/deletion polymorphism in Egyptian patients with myocardial infarction. Journal of Renin-Angiotensin-Aldosterone System. June 2009; vol. 10 no. 2: 96-100

[28] Cambien F, Poirier O, Lecerf L; et al. Deletion polymorphism in the gene for angiotensin-converting enzyme is a potent risk factor for myocardial infarction. Nature. 1992; 359(6396):641-644.

[29] Ludwig EH, Borecki IB, Ellison RC, Folsom AR, Heiss G, Higgins M, Lalouel JM, Province MA, Rao DC, Association between candidate loci angiotensine converting enzyme and angiotensinogen with coronary heart disease and myocardial infarction: the NHLBI family heart study. Ann Epidemiol. 1997; 7 (1)3-12.

[30] Fatini C., Abbate R., Pepe G. et al. Searching for a better assessment of the individual coronary risk profile. The role of angiotensin-converting enzyme, angiotensin II type 1 receptor and angiotensinogen gene polymorphisms. Eur Heart J. 2000; 21:633-8.

[31] Sekuri C, Cam FS, Ercan E, et al. Renin-angiotensin system gene 4. polymorphisms and premature coronary heart disease. J Renin Angiotensin Aldosterone System. 2005; 6(1):38-42.

[32] Freitas AI, Mendonça I, Brión M, Sequeira MM, Reis RP, Carracedo A, Brehm A. RAS gene polymorphisms, classical risk factors and the advent of coronary artery disease in the Portuguese population. BMC Cardiovasc Disorder. 2008 Jul 17; 8:15.

[33] Danser AHJ, Schalekamp MADH, Bax WA et al.Angiotensin converting enzyme in the human heart: Effects ofthe deletion/insertion polymorphism. Circulation 1995; 92:1388-9.

[34] Schunkert H. Polymorphism of the angiotensin converting enzyme gene and cardiovascular disease. J Mol Med 1997; 75:867-75.

[35] Pratt, J.H., Rothrock, J.K. and Dominguez, J.H., Evidence that angiotensin II and potassium collaborate to increase cytosolic calcium and stimulate the secretion of aldosterone. Endocrinology, 1989, 125,2463-2469.

[36] Otani, A., Takagi, H., Suzuma, K. and Yoshihito, R., Angiotensin II potentiates vascular endothelial growth factor-induced angiogenic activity in retinal microcapillary endothelial cells. Circ. Res., 1998, 82,619-628.

[37] Mendonca I, IA Freitas, CA Sousa, S Gomes et al. Polymorphism of the ACE gene is associated with extent and severity of coronary disease.Rev Port Cardiol. 2004; 23: 1605-11.

[38] Hibi K, Ishigami T, Kimura K, Nakao M, Iwamoto T, Tamura K, Nemoto T, Shimizu T, Mochida Y, Ochiai H, Umemura S, Ishii M. Angiotensin-converting enzyme gene polymorphism adds risk for the severity of coronary atherosclerosis in smokers. Hypertension. 1997; 30: 574-579.

[39] Jeunemaitre X, Soubrier F, Kotelevtsev YV, Lifton RP, Williams CS, Charru A, Hunt SC, Hopkins PN, Williams RR, Lalouel JM, Corvol P. Molecular basis of human hypertension: Role of angiotensinogen. Cell 1992;71: 169-180.

[40] Rotimi C, Morrison L, Cooper R, Oyegide C, Effiong E, Ladipo M, Osotemihen B, Ward R. Angiotensinogen gene in human hypertension, lac of an association of the 235T allele among African Americans. Hypertension. 1994; 24:591-594.

[41] Fornage M, Turner ST, Sing CF, Boerwinkle E. Variation at the M235T locus of the angiotensinogen gene and essential hypertension: a population based case control study from Rochester, Minnesota. Hum Genet. 1995; 96:295-300.

[42] Gould AB, Green D. Kinetics of the human rennin and human substrate reaction. Cardiovasc Res 1971; 5: 86-89

[43] Ishigam T, Umemura S, Iwamoto T et al. Molecular variant of angiotensinogen gene is associated with coronary atherosclerosis. Circulation 1995;91:951-4.

[44] Lanz JR, Pereira AC, Lemos PA, et al. Angiotensinogen M235T polymorphism is associated with coronary artery disease severity. Clin Chim Acta 2005 ; 362: 176-81. 
[45] Jeunemaitre X, Inoue I, Williams C, Charru A, Tichet J, Powers M, Sharma AM, Gimenez-Roqueplo AP, Hata A, Corvol P, Lalouel JM. Haplotypes of angiotensinogen in essential hypertension. Am J. Hum. Genet. 1997; 60: 1448-1460.

[46] Pereira AC, Mota GF, Cunha RS, et al. Angiotensinogen 235T allele dosage is associated with blood pressure phenotypes. Hypertension 2003; 41: 25-30.

[47] Meheri S, Mahjoub S, Farhati A, Bousaada R, Ben Arab S, Baudin B, Hammami M. Angiotensinogen gene polymorphism in acute myocardial infarction patients. J Renin Angiotensin Aldosterone Syst. 2011 Mar; 12(1):42-7.

[48] Gardemann A., Stricker J., Humme J. et al. Angiotensinogen T174M and M235T gene polymorphisms are associated with the extent of coronary atherosclerosis. Atherosclerosis 1999; 145:309-14.

[49] Guo D, Yulin S, Pavel H, Tadashi I. The angiotensin II type I receptor and receptor associated proteins. Cell Res 2001;11:165-80.

[50] Geel VP, Pinto YM, Zwinderman AH, Henning RH, van Boven AJ, Jukema JW, Bruschke AV, Kastelein JJ, van Gilst WH. Increased risk for ischaemic events is related to combined RAS polymorphism. Heart. April 2001; 85(4):458-62.

[51] Pullareddy BR, Baddela Muni Venkata Srikanth Babu, Kolla Venkata Karunakar, Jeedigunta Yasovanthi. Angiotensin II type 1 receptor gene polymorphism in myocardial infarction patients. Journal of Renin-Angiotensin-Aldosterone System. 2009; 10: 174

[52] Peng J, Peng S, Gong W. [Association between early-onset coronary heart disease and angiotensin II type 1 receptor gene polymorphism]. Zhonghua Yi Xue Za Zhi. 2002 Apr 10;82(7):471-3.

[53] Araujo MA, Menezes BS, Lourenco C., Cordeiro ER, Gatti RR, Goulart LR The A1166C polymorphism of the angiotensin II type-1 receptor in acute myocardial infarction. Arq Bras Cardiol. $2004 ; 83: 409-13$.

[54] Mehmet SU, Onder O, Mehmet Y et al. Association between A/C 1166 gene polymorphism of the angiotensin II type 1 receptor and biventricular functions of patients with acute myocardial infarction. Circ J 2006;70:1275-9.

[55] Kee F., Morrison C., Poirier O. et al. Angiotensin II type-I receptor and ACE polymorphisms and risk of myocardial infarction in men and women. Eur J Clin Invest 2000;30:1076-82.

[56] Buraczyska M, Pijanowski Z, Spasiewicz D,Nowicka T, Sodolski T, Widomska-Czekajska T, et al. Renin-angiotensin system gene polymorphisms:Assessment of the risk of coronary heart disease. Kardiol Pol. 2003; 58:1-8.

[57] Assali A, Javad Behravan, roghayeh Paydar, Mohsen Mouhebati et al. Association between angiotensin II type-1 receptor A1166C polymorphism and the presence of angiographically-defined coronary artery disease in an Iranian population. Asian biomedicine April 2010; vol.4 no.2:307-314.

Table 1. Age and sex distribution of Cases

\begin{tabular}{|c|c|c|c|}
\hline Age in years & CAD cases & Male & Female \\
\hline Up to 40 & 18 & 15 & 03 \\
\hline $41-50$ & 36 & 30 & 06 \\
\hline $51-60$ & 50 & 37 & 07 \\
\hline $61-70$ & 36 & 29 & 00 \\
\hline $71-80$ & 9 & 09 & 00 \\
\hline More than 80 & 1 & 01 & 29 \\
\hline Total & 150 & 121 & 13 \\
\hline
\end{tabular}

CAD- Coronary Artery Disease

Table II. Risk factor analysis in CAD Cases

\begin{tabular}{|c|c|c|}
\hline Risk factors & Number (150) & Percentage \\
\hline Hypertension(HTN) & 73 & $48.6 \%$ \\
\hline Diabetes mellitus (DM) & 50 & $33.3 \%$ \\
\hline Dyslipidemia (Tc >200 mg/dl) & 41 & $27.3 \%$ \\
\hline Smoking(SM) & 39 & $26.0 \%$ \\
\hline Family history of CAD & 24 & $16.0 \%$ \\
\hline Obese & 10 & $6.0 \%$ \\
\hline Overweight & 67 & $44.6 \%$ \\
\hline No risk factors & 34 & $22.6 \%$ \\
\hline
\end{tabular}

HTN - Hypertension, DM - diabetes mellitus, SM - smoking, CAD - coronary artery disease, F/H -family history.

Table III. Demographic and clinical data

\begin{tabular}{|c|c|c|}
\hline Variables & $\begin{array}{c}\text { CAD cases } \\
\mathrm{n}=150\end{array}$ & $\begin{array}{c}\text { Controls } \\
\mathrm{n}=150\end{array}$ \\
\hline Age (years) & $54.6 \pm 11.4$ & $54.6 \pm 11.0$ \\
\hline Sex( M/F) & $121 / 29$ & $118 / 32$ \\
\hline SVD & $51(34.0 \%)$ & 0 \\
\hline DVD & $17(11.3 \%)$ & 0 \\
\hline TVD & $82(54.6 \%)$ & 0 \\
\hline AMI & $117(78 \%)$ & 0 \\
\hline Unstable angina & $33(22 \%)$ & NIL \\
\hline Morbidity & $37(24.66 \%)$ & NIL \\
\hline Mortality & $8(5.3 \%)$ & . \\
\hline
\end{tabular}

BMI-Body mass index, RBS-Random blood sugar, SVD- Single vessel disease, DVD-Double vessel disease, TVD-Triple vessel disease, AMI-Acute myocardial infarction

Table IV. Frequency distribution of ACE, AGT and AR1R gene in cases and controls 


\begin{tabular}{|c|c|c|c|c|c|c|}
\hline Genotypes & $\begin{array}{c}\text { Cases } \\
\mathrm{n}=150\end{array}$ & $\begin{array}{c}\text { Controls } \\
\mathrm{n}=150\end{array}$ & $\chi^{2}$ & P value & $\begin{array}{c}\text { Odds } \\
\text { ratio }\end{array}$ & $95 \%$ CI \\
\hline ACE DD & $54(36 \%)$ & $75(50.0 \%)$ & 5.9 & 0.01 & 0.56 & $0.35-0.89$ \\
\hline ACE ID & $45(30 \%)$ & $41(27.3 \%)$ & 0.26 & 0.60 & 1.13 & $0.69-1.88$ \\
\hline ACE II & $51(34 \%)$ & $34(22.7 \%)$ & 4.5 & 0.03 & 1.74 & $1.05-2.92$ \\
\hline AGT MM & $35(23.3 \%)$ & $71(47.3 \%)$ & 18.91 & 0.00001 & 0.33 & $0.20-0.55$ \\
\hline AGT MT & $57(38 \%)$ & $49(32.6 \%)$ & 0.93 & 0.33 & 1.26 & $0.78-2.03$ \\
\hline AGT TT & $58(38.6 \%)$ & $30(20 \%)$ & 12.61 & 0.0003 & 2.52 & $1.50-4.23$ \\
\hline AT1R AA & $132(88 \%)$ & $135(90 \%)$ & 0.30 & 0.58 & 0.81 & $0.05-0.09$ \\
\hline AT1R AC & $18(12 \%)$ & $15(10 \%)$ & 0.30 & 0.58 & 1.22 & $0.09-0.05$ \\
\hline AT1R CC & 0 & 0 & 0 & 0 & 0 & 0 \\
\hline
\end{tabular}

Table V. Severity in Cases with and without risk factors

\begin{tabular}{|c|c|c|c|c|}
\hline Vessel disease & $\begin{array}{c}\text { Cases without any } \\
\text { risk factors } \\
\mathrm{n}=34\end{array}$ & $\begin{array}{c}\text { Cases with risk } \\
\text { factors } \\
\mathrm{n}=116\end{array}$ & $\chi^{2}$ & P value \\
\hline SVD & $14(41.2 \%)$ & $37(31.9 \%)$ & \multirow{2}{*}{0.30} & \multirow{2}{*}{0.57} \\
\hline DVD & $01(2.9 \%)$ & $16(13.8 \%)$ & \\
\hline TVD & $19(55.9 \%)$ & $63(54.3 \%)$ & \\
\hline
\end{tabular}

SVD- single vessel disease, DVD- double vessel disease, TVD- triple vessel disease

Table VI. Genotype and allele frequencies of Alu ACE I/D polymorphism in the CAD patients based on

\begin{tabular}{|c|c|c|c|c|c|c|c|}
\hline & $\begin{array}{l}\text { TVD } \\
\mathrm{N}=82\end{array}$ & $\begin{array}{l}\text { DVD } \\
N=17\end{array}$ & $\chi^{2}$ & $\begin{array}{l}\mathrm{P} \\
\text { value }\end{array}$ & $\begin{array}{c}\text { SVD } \\
N=51\end{array}$ & $\chi^{2}$ & P value \\
\hline \multicolumn{8}{|l|}{$\begin{array}{l}\text { Genotype } \\
\text { frequencies }\end{array}$} \\
\hline DD & $43(52.4 \%)$ & $1(5.8 \%)$ & \multirow[t]{3}{*}{15.82} & \multirow[t]{3}{*}{0.0003} & $7(13.7 \%)$ & \multirow[t]{3}{*}{43.33} & \multirow[t]{3}{*}{0.000} \\
\hline ID & $28(34.1 \%)$ & $8(47.05 \%)$ & & & $9(17.6 \%)$ & & \\
\hline II & $11(13.4 \%)$ & $8(47.05 \%)$ & & & $35(68.6 \%)$ & & \\
\hline \multicolumn{8}{|l|}{$\begin{array}{c}\text { Allele } \\
\text { frequencies }\end{array}$} \\
\hline $\mathrm{D}$ & 0.70 & 0.29 & \multirow[t]{2}{*}{20.5} & \multirow[t]{2}{*}{0.00007} & 0.22 & \multirow[t]{2}{*}{54.72} & \multirow[t]{2}{*}{0.000} \\
\hline I & 0.31 & 0.71 & & & 0.78 & & \\
\hline
\end{tabular}

the number of affected coronary vessels.

CAD - coronary artery disease, SVD- single vessel disease, DVD- double vessel disease, TVD- triple vessel disease,

Table VII. Genotype and allele frequencies of AGT/ M235T polymorphism in the CAD patients based on

\begin{tabular}{|c|c|c|c|c|c|c|c|}
\hline & $\begin{array}{r}\text { TVD } \\
\mathrm{N}=82\end{array}$ & $\begin{array}{l}\text { DVD } \\
\mathrm{N}=17\end{array}$ & $x^{2}$ & $\begin{array}{c}\mathrm{P} \\
\text { value }\end{array}$ & $\begin{array}{l}\text { SVD } \\
\mathrm{N}=51\end{array}$ & $x^{2}$ & $P$ value \\
\hline $\begin{array}{l}\text { Genotype } \\
\text { frequencies }\end{array}$ & & & & & & & \\
\hline MM & $14(17.07 \%)$ & $4(23.5 \%)$ & \multirow[b]{3}{*}{8.20} & \multirow[b]{3}{*}{0.016} & $17(33.3 \%)$ & \multirow[b]{3}{*}{5.84} & \multirow[b]{3}{*}{0.05} \\
\hline MT & $28(34.1 \%)$ & $11(64.7 \%)$ & & & $18(35.2 \%)$ & & \\
\hline TT & $40(48.7 \%)$ & $2(11.7 \%)$ & & & $16(31.3 \%)$ & & \\
\hline $\begin{array}{c}\text { Allele } \\
\text { frequencies }\end{array}$ & & & & & & & \\
\hline $\mathrm{M}$ & 0.34 & 0.55 & \multirow[b]{2}{*}{5.6} & \multirow[b]{2}{*}{0.017} & 0.50 & \multirow[b]{2}{*}{6.57} & \multirow[b]{2}{*}{0.010} \\
\hline $\mathrm{T}$ & 0.66 & 0.45 & & & 0.50 & & \\
\hline
\end{tabular}

the number of affected coronary vessels.

CAD - coronary artery disease, SVD- single vessel disease, DVD- double vessel disease, TVD- triple vessel disease, 
Association of ACE, AGT and ATIR gene polymorphisms with severity of Coronary Artery Disease

Table VIII. Genotype and allele frequencies of AT1R / A1166C polymorphism in the CAD patients based

\begin{tabular}{|c|c|c|c|c|c|c|c|}
\hline & $\begin{array}{l}\text { TVD } \\
\mathrm{N}=82\end{array}$ & $\begin{array}{l}\text { DVD } \\
\mathrm{N}=17\end{array}$ & $\chi^{2}$ & $\begin{array}{c}\mathrm{P} \\
\text { value }\end{array}$ & $\begin{array}{l}\text { SVD } \\
\mathrm{N}=51\end{array}$ & $x^{2}$ & $P$ value \\
\hline $\begin{array}{l}\text { Genotype } \\
\text { frequencies }\end{array}$ & & & & & & & \\
\hline $\mathrm{AA}$ & $69(84.1 \%)$ & $14(82.3 \%)$ & \multirow{3}{*}{0.03} & \multirow{3}{*}{0.85} & $49(96.1 \%)$ & \multirow{3}{*}{4.47} & \multirow{3}{*}{0.034} \\
\hline $\mathrm{AC}$ & $13(15.8 \%)$ & $3(17.6 \%)$ & & & $2(3.9 \%)$ & & \\
\hline $\mathrm{CC}$ & 0 & 0 & & & 0 & & \\
\hline $\begin{array}{c}\text { Allele } \\
\text { frequencies }\end{array}$ & & & & & & & \\
\hline $\mathrm{A}$ & 0.92 & 0.91 & \multirow[b]{2}{*}{0.03} & \multirow[b]{2}{*}{0.86} & 0.98 & \multirow[b]{2}{*}{5.93} & \multirow[b]{2}{*}{0.014} \\
\hline $\mathrm{C}$ & 0.08 & 0.09 & & & 0.02 & & \\
\hline
\end{tabular}

on the number of affected coronary vessels.

CAD - coronary artery disease, SVD- single vessel disease, DVD- double vessel disease, TVD- triple vessel disease, 